\title{
Age of Transplant and Row Spacing Effects on Growth, Yield and Yield Components of Chilli Pepper (Capsicum annuum L.)
}

\author{
M. E. Essilfie ${ }^{1 *}$, H. K. Dapaah², E. Boateng ${ }^{1}$, R. J. Damoah ${ }^{1}$ \\ 1* Department of crop and soil sciences Education, Faculty of Agriculture Education, University of Education, Winneba P.O. Box \\ 40, Mampong-Ashanti. maggifremp@yahoo.co.uk. \\ ${ }^{2}$ University of Energy and Natural Resources. P.O.Box 214, Sunyani. hkdapaah@yahoo.com
}

\begin{abstract}
Two field experiments were conducted for two years (2013 and 2014) at the Multipurpose crop nursery of the University of Education, Winneba, Mampong-campus from May to September to evaluate the effect of three transplanting ages $(30,37$ and 44 days) and four row spacing $(30 \times 30 \mathrm{~cm}, 40 \times 30 \mathrm{~cm}, 50 \times 30 \mathrm{~cm}$ and $60 \times$ $30 \mathrm{~cm})$ on growth, yield and yield components of pepper. The experimental design used was a $3 \times 4$ factorial in randomized complete block design with three replicates for both experiments. The results showed that 44 aged transplants had the highest yield during the 2013 cropping season, tallest plant in both cropping seasons, highest number of branches and canopy width for the entire 2014 cropping season. The 30 aged transplants differed significantly from the other aged transplants in number of fruits per plant and widest fruit diameter during the 2013 cropping season. The $40 \times 30 \mathrm{~cm}$ row spacing had the tallest plant and highest number of branches from 8 to 10 weeks after transplanting in both cropping seasons. The 30 $x 30 \mathrm{~cm}$ row spacing differed significantly from the $50 \times 30$ $\mathrm{cm}$ and $60 \times 30 \mathrm{~cm}$ row spacing in fruit yield during the 2013 cropping season. The $60 \times 30 \mathrm{~cm}$ row spacing had the longest fruit length and the heaviest fruit weight per plant during the 2013 cropping season. It is concluded that for high fruit yield, farmers are to transplant pepper seedlings at 44 days using $30 \times 30 \mathrm{~cm}$ row spacing.
\end{abstract}

Keywords - Age of transplant, row spacing, pepper, fruit yield, yield components.

\section{INTRODUCTION}

Pepper (Capsicum annuиm, L.) (Bell Pepper, Sweet Pepper, Cayenne or Round Chilli) is one of the two cultivated hot pepper species in Ghana, and occurs in two major fruit forms recognized locally as 'Kpakposhito' ( bell pepper, small round- shaped fruits, hot) and 'Legon 18' (Cayenne red, bell- shaped fruits, hot). Pepper is very popular in all the agro-ecological zones of Ghana even though production is mainly under rain-fed conditions. Ghana ranked the $11^{\text {th }}$ largest producer of pepper in the world and the $2^{\text {nd }}$ largest producer in Africa with an estimated total production of 88,000 metric tons in 2011 which accounted for $£ 96,397$ FAOSTAT, (2011). It is estimated that pepper growers in Ghana are producing about $50 \%$ of the attainable yields MiDA, (2010). The low production may be attributed to inappropriate use of cultural practices. Cultural factors such as transplant age, geographical location of transplant production (Weston, 1988) and plant spacing (Stofella and Bryan, 1988) influenced pepper yield. Modern vegetable production practices emphasize the need to use optimum plant population attained with appropriate spacing Sayed and Hossein, (2010). Plant spacing can influence morphological development of pepper including reproduction characteristics. Competition for available water and mineral nutrients from the soil and light is greater at high plant population densities. Environmental factors, especially light intensity, stimulate the process of photosynthesis which, in turn, affects biomass production and is closely associated with plant growth rate Alabi et al., (2014). In plant densities studies, inter-plant competition is one of the most important stress affecting biomass production, crop yield and economic profitability Naser, et $a l$. , (2013). Even though pepper is popular in all the agroecological zones of Ghana, very little has been achieved in the improvement of the indigenous cultivars probably due to limited information on the use of appropriate cultural practices. The study was conducted to determine the effects of ages of transplanting and different row spacing on growth, yield and yield components of chilli pepper and with the results make a recommendation that will be a component improved practices for pepper cultivation. 


\section{MATERIALS AND METHODS}

\subsection{Description of Study Area}

Two field experiments were conducted at the Multipurpose crop nursery of the University of Education, Winneba, Mampong- Ashanti campus for two consecutive years (2013 and 2014) from May to September. The soil type is the savannah ochrosol formed from the Voltaian sandstone of the Afram plains. Texturally, the soil is friable with a thin layer of organic matter and is deep and brown-sandy loam and well-drained. It however, has a good water holding capacity. The soil has been classified by FAO / UNESCO legend as Chronic Luvisol and locally as the Bediesi series with a $\mathrm{pH}$ range of 4.0-6.5.

The weather conditions during the experimental periods show that differences in climatic factors (rainfall, temperature and relative humidity) were observed between cropping seasons. In the 2013 cropping season, the total monthly rainfall was $686.1 \mathrm{~mm}$ and it occurred from May to September with the peak in May and September (Table 1). The mean monthly temperature of the site for the 2013 cropping season ranged between $21.5{ }^{\circ} \mathrm{C}$ to $48.3{ }^{\circ} \mathrm{C}$, with the highest daily of $48.3{ }^{\circ} \mathrm{C}$ occurring in July. The mean monthly relative humidity ranged from 63.0 to $97.0 \%$ with the peak occurring in May, July and September. For the 2014 cropping season, the total monthly rainfall was 712.8 $\mathrm{mm}$ and it occurred from May to September with the peak in June and July (Table 1). The mean monthly temperature of the site for the 2014 cropping season ranged between $22.0{ }^{\circ} \mathrm{C}$ to $34.7{ }^{\circ} \mathrm{C}$, with the highest daily of $34.7{ }^{\circ} \mathrm{C}$ occurring in May. The mean monthly relative humidity ranged from 61.0 to $96.0 \%$ with the peak occurring between June and July.

\subsection{Experimental Design and Planting}

The experimental design used for both study was a $3 \times 4$ factorial arranged in randomized complete block design (RCBD) with three replicates made up of three transplanting ages (30, 37 and 44 days ) and four row spacing $(30 \times 30 \mathrm{~cm}, 40 \times 30 \mathrm{~cm}, 50 \times 30 \mathrm{~cm}$ and $60 \times 30 \mathrm{~cm})$ was assign to each block. The total field size of $33.6 \mathrm{~m} \mathrm{x}$ $13.0 \mathrm{~m}\left(436 \mathrm{~m}^{2}\right)$ was cleared followed by ploughing and harrowing as there were no stumps. Each plot measured 1.2 $\mathrm{m} \times 3.0 \mathrm{~m}, 1.6 \mathrm{~m} \times 3.0 \mathrm{~m}, 2.0 \times 3.0 \mathrm{~m}$ and $2.4 \times 3.0 \mathrm{~m}$ based on the respective row spacing with $1.0 \mathrm{~m}$ left between each treatment plot. Cayenne variety of hot pepper was used. Each plot had 4 rows of 40 plants.

Table.1: Climate data for 2013 and 2014 Experimental periods

\begin{tabular}{|c|c|c|c|c|c|c|c|c|c|c|}
\hline \multirow[t]{3}{*}{ Month } & \multicolumn{2}{|c|}{$\begin{array}{l}\text { Total monthly } \\
\text { Rainfall (mm) }\end{array}$} & \multicolumn{4}{|c|}{$\begin{array}{l}\text { Mean monthly Relative humidity (\%) } \\
\text { (hours GMT) }\end{array}$} & \multicolumn{4}{|c|}{ Mean monthly temperature $\left({ }^{\circ} \mathrm{C}\right)$} \\
\hline & \multirow[b]{2}{*}{2013} & \multirow[b]{2}{*}{2014} & \multirow{2}{*}{$\begin{array}{r}06.00 \\
2013\end{array}$} & \multirow{2}{*}{$\begin{aligned} 06.00 \\
2014\end{aligned}$} & \multirow{2}{*}{$\frac{15.00}{2013}$} & \multirow{2}{*}{$\begin{array}{r}15.00 \\
2014\end{array}$} & \multicolumn{2}{|c|}{ Minimum } & \multicolumn{2}{|c|}{ Maximum } \\
\hline & & & & & & & 2013 & 2014 & 2013 & 2014 \\
\hline May & 207.4 & 121.4 & 97 & 61 & 63 & 95 & 22.7 & 23.7 & 31.6 & 34.7 \\
\hline June & 114.9 & 336.4 & 96 & 69 & 71 & 96 & 22.6 & 22.6 & 30.0 & 32.2 \\
\hline July & 138.0 & 131.4 & 97 & 67 & 71 & 96 & 21.9 & 22.8 & 48.3 & 31.6 \\
\hline August & 6.0 & 3.9 & 95 & 69 & 71 & 94 & 21.5 & 22.0 & 27.7 & 30.6 \\
\hline $\begin{array}{l}\text { Septem } \\
\text { ber }\end{array}$ & 219.8 & 119.7 & 97 & 64 & 70 & 95 & 22.9 & 22.5 & 29.6 & 32.3 \\
\hline Total & 686.1 & 712.8 & & & & & & & & \\
\hline
\end{tabular}

(Meteorological Department - Mampong -Ashanti, 2013, 2014)

\subsection{Data Collection and Analysis}

Number of leaves per plant was counted on three plants from the two central rows, plant height was measured on three plants, canopy width was measured on three plants, while three plants were randomly sampled for the dry matter accumulation. Data were collected at three weeks after transplanting and at two weeks interval. Number of plants harvested, number of fruits per plant, fruit weight per plant, total fruit yield and yield components including fruit diameter and fruit length were estimated from the two central rows. Data analysis was done using analysis of variance and Statistical Analysis System software, version 
9.0 (SAS, 2002). Least significant difference (LSD) was used to separate means at $5 \%$ level of probability.

\section{RESULTS AND DISCUSSION}

\subsection{Vegetative Growth}

\subsubsection{Plant height}

The plant height responded significantly to variation in ages of transplant during the two year cropping seasons. There was a significant difference between 44 aged transplants from 30 and 37 aged transplants in plant height from 2 to 6 weeks after transplanting (WAT) during the 2013 cropping season (Fig. 1). This contradicts with the findings of (Ibrahim et al., 2013) that transplanting of pepper at younger age was better in performance, especially in height than those transplanted later. Plant height however, was not significantly affected by age of transplant from 8 to 10 WAT at the same cropping season. The 44 aged transplants differed significantly from 30 and 37 aged transplants in plant height for the entire 2014 cropping period. Increased plant height in 44 aged transplants might be that in younger seedlings there was less stored food needed for vegetative extension while the older transplants switched over to reproductive phase earlier and had little time for establishment. The length of seedlings at transplanting increased with increase in seedling age. Increased plant height in older transplants might also be attributed to higher biomass, especially the well developed and established root system which resulted into more uptake of water and nutrients from the soil leading to better cellular elongation. Similar trends have also been reported by Lee Jiwon et al., (2001).

The $30 \times 30 \mathrm{~cm}$ and $40 \times 30 \mathrm{~cm}$ row spacing produced the tallest plant height for the entire 2013 cropping season (Fig. 1). The $40 \mathrm{~cm} \times 30 \mathrm{~cm}$ row spacing however, produced the tallest plant from 6 to 10 WAT during the 2014 cropping season (Fig. 1). This shows that lower inter row spacing resulted in increased plant height. This might be due to maximum competition for light and air and probably in relation to lower competition for physical production resources (soil moisture and nutrients) which would enhance nutrient availability and efficient utilization of assimilates. This agrees with (Alabi et al., 2014) that plants grow taller at narrower row spacing, and that taller plants were observed as plant population reduced. Peppers and other plants grown in denser population tend to be taller than those grown in less dense planting Stofella and Bryan, (1988).

\subsubsection{Number of leaves per plant}

The 37 aged transplants produced the highest number of leaves per plant for the entire 2013 cropping season (Fig. 2). There was a significant difference between 44 aged transplants from 30 and 37 aged transplants in number of leaves per plant from 2 to 6 WAT during the 2014 cropping season (Fig. 2). This might be due to older aged transplants used. Older transplants with sufficient number of true leaves might be responsible for manufacturing a sizable amount of photosynthates required to establish vigorous plant and complete its life cycle more comfortably YR Shukla, and Rajender, (2011). There was no significant difference between ages of transplant at $8 \mathrm{WAT}$ at the same cropping season.

There was no significant difference between row spacing treatments in number of leaves per plant during the 2013 cropping season although differences exist between treatment means with $40 \times 30 \mathrm{~cm}$ producing the highest number of leaves per plant from 4 to 8 WAT( Fig. 2). The $60 \times 30 \mathrm{~cm}$ row spacing produced the least number of leaves per plant from 6 to $8 \mathrm{WAT}$ at the same cropping period (Fig. 2). This is in contrast to (Islam et al., 2011) that wider spacing gave high number of leaves per plant. The 40 x $30 \mathrm{~cm}$ row spacing produced the highest number of leaves per plant for the entire 2014 cropping season (Fig. 2). This might be due to the fact that plant density affected leaf formation and development in response to competition for available space for nutrient absorption which would influence plant vegetative growth and development. This agrees with the findings of (Rafiei, 2009; Albayrak et al., 2011; Ciampitti and Vyn, 2011) that for most crops, plant density has a major influence on biomass.

\subsubsection{Number of branches}

The 37 aged transplants produced the highest number of branches from 8 to 10 WAT and the least with the 30 aged transplants during the 2013 cropping season (Fig. 3). This contradicts with the findings of (Ibrahim et al., 2013) that pepper transplanted earlier gave higher number of branches than those transplanted later. There were no branches observed in the three different aged transplants at 2 WAT during the 2014 cropping season (Fig. 3). The 44 aged transplants produced the highest number of branches from 4 to 8 WAT at the same cropping season. The 30 and 44 aged transplants produced the same number of branches at 10 WAT at the same cropping period. The 37 aged transplants had the least number of branches from 8 to 10 WAT during the 2014 cropping season (Fig. 3). The poor performance of 30 and 37 aged transplants during 2013 and 2014 cropping seasons from 8 to 10 WAT respectively might be due to 
differences in plant morphology and its response to high temperature tolerance experienced during the later stage of plant development.

The $30 \times 30 \mathrm{~cm}$ and $40 \times 30 \mathrm{~cm}$ row spacing produced the highest and the same number of branches from 4 to 10 WAT during the 2013 cropping season (Fig. 3). There were no branches observed in the different row spacing treatments at 2 WAT during the 2014 cropping season (Fig. 3). The $30 \times 30 \mathrm{~cm}$ and $40 \times 30 \mathrm{~cm}$ produced the highest and the same number of branches at 4 WAT at the same cropping period. The $30 \times 30 \mathrm{~cm}$ row spacing had the highest number of branches at 6 WAT during 2014 cropping season. The $40 \times 30 \mathrm{~cm}$ row spacing produced the highest number of branches from 8 to 10 WAT during the 2014 cropping season followed by the $30 \times 30 \mathrm{~cm}$ row spacing (Fig. 3). This is an indication that when inter row spacing increase, the number of branches per plants per unit area becomes less. This contradicts with the findings of (Sarfo-Kantanka and Lawson, 1980) that plants develop fewer branches at narrower row spacing.

\subsubsection{Canopy Width}

The 44 aged transplants produced the widest canopy width from 2 to 4 WAT during the 2013 cropping season (Fig. 4). The 37 and 44 aged transplants produced the widest and the same canopy width from 6 to 10 WAT at the same cropping period. This might be due to older aged transplants used and differences in plant morphology.

The 30 aged transplants had the least canopy width from 4 to 10 WAT during the 2013 cropping season (Fig. 4). The 44 aged transplants produced the widest canopy width for the entire 2014 cropping season (Fig. 4). The 30 aged transplants produced the least canopy width from 2 to 4 WAT and the 37 aged transplants from 6 to $10 \mathrm{WAT}$ at the same cropping period (Fig. 4).

The $40 \times 30 \mathrm{~cm}$ row spacing had the widest canopy width at 4 WAT and from 8 and 10 WAT during the 2013 cropping season and for the entire 2014 cropping period (Fig. 4). This might be due to differences in plant morphology and plant spacing. Plants with increased canopy width tend to have higher photosynthetic potential (NAR). The $50 \times 30 \mathrm{~cm}$ row spacing had the lowest canopy width for the entire 2013 and 2014 cropping periods (Fig. 4). This might be due to differences in plant spacing and its effect on plant structure. Plant density can affect canopy architecture, light conversion efficiency and duration of vegetative growth. Therefore, optimising plant density, which could be defined by both the number of plants per unit area and the arrangement of plants on the ground, is a pre-requisite for obtaining higher biomass hence canopy width.

\subsubsection{Dry matter Accumulation}

The 44 aged transplants produced the highest dry matter accumulation for the entire 2013 cropping period followed by 37 aged transplants (Fig. 5). The increased dry matter accumulation in 44 aged transplants might be that at this stage, the stem had developed more branches, become woody and so steadily accounted for increasing part of the total dry matter produced. The 30 aged transplants had the least dry matter accumulation for the entire 2013 cropping period (Fig. 5). The 37 aged transplants produced the highest dry matter accumulation from 2 to 4 WAT and at 8 WAT for the 2014 cropping season (Fig. 5). The 44 aged transplants had the least dry matter accumulation from 2 to 4 WAT followed by the 30 aged transplants from 6 to 8 WAT at the same cropping period. This might be due to differences in transplanting ages of seedlings, plant morphology and climatic conditions. The plant dry matter accumulation increased linearly in the later stages of plant development. This is an indication that the large plant size starts to compete mainly for water, light and nutrients thereby resulted in higher dry matter accumulation in the older aged transplants.

Row spacing had no significant effect on dry matter accumulation at 2 WAT in both cropping seasons (Fig. 5). The pepper plants increased linearly in dry matter accumulation for the entire cropping period in both seasons. The $40 \times 30 \mathrm{~cm}$ produced the highest dry matter accumulation from 6 to 8 WAT during the 2013 cropping season. Higher dry matter yield might be due to differences in plant structure and row spacing. The $60 \times 30 \mathrm{~cm}$ row spacing had the least dry matter accumulation for the entire 2013 cropping season (Fig. 5). However, the $60 \times 30 \mathrm{~cm}$ row spacing had the highest dry matter accumulation from 4 to 8 WAT during the 2014 cropping season (Fig. 5). This might be due to the root and leaf dry matter yields on account of more branches and leaves produced and increase in stem dry weight. Plant density can affect dry matter production and ultimately, the economic productivity of a crop. 

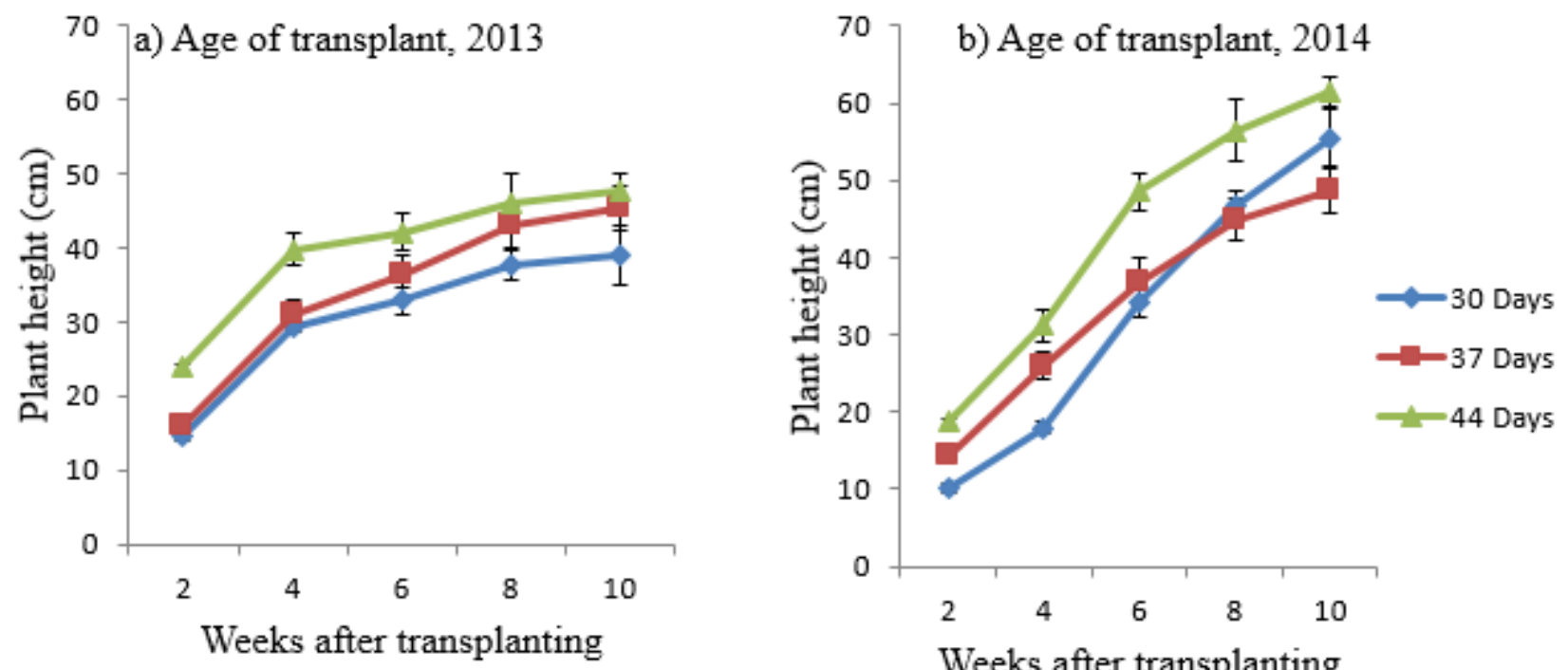

Weeks after transplanting
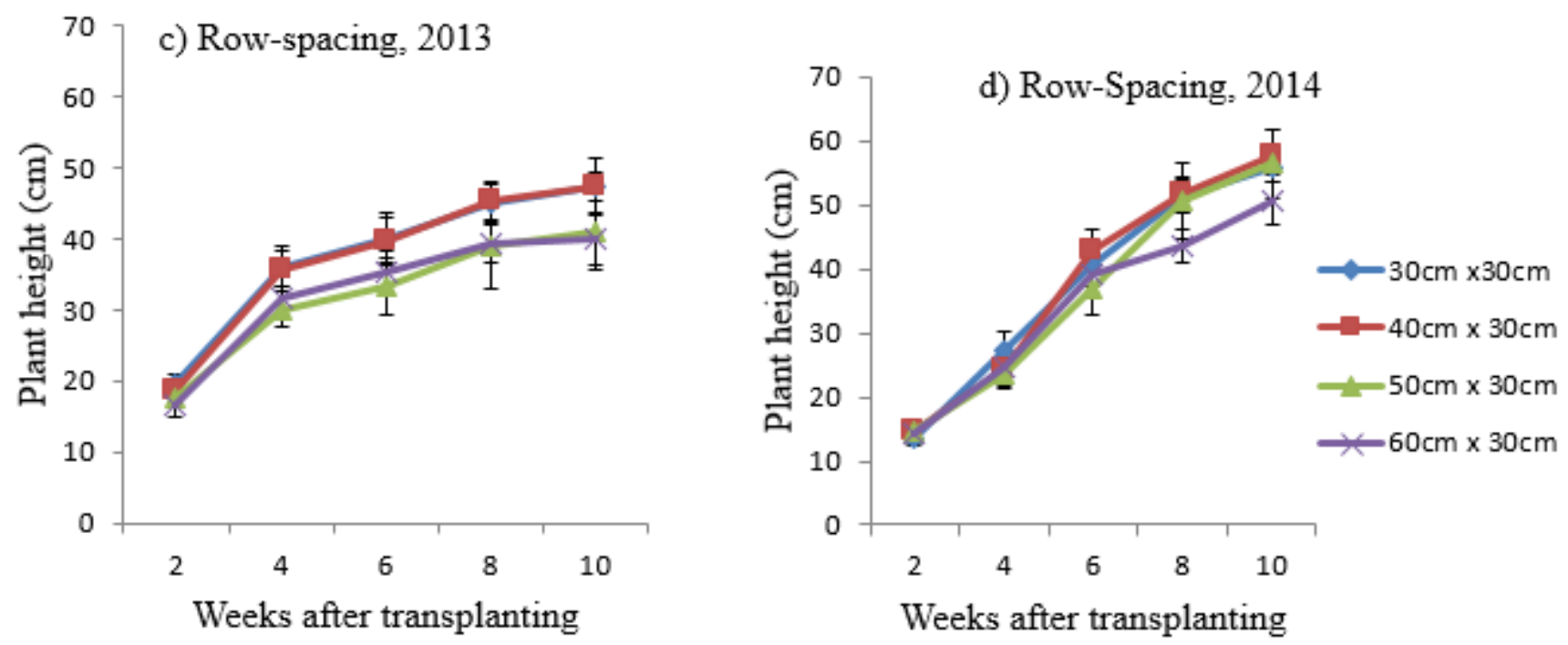

Fig.1: Effects of age of transplant and row-spacing on plant height of chilli pepper, 2013 and 2014 

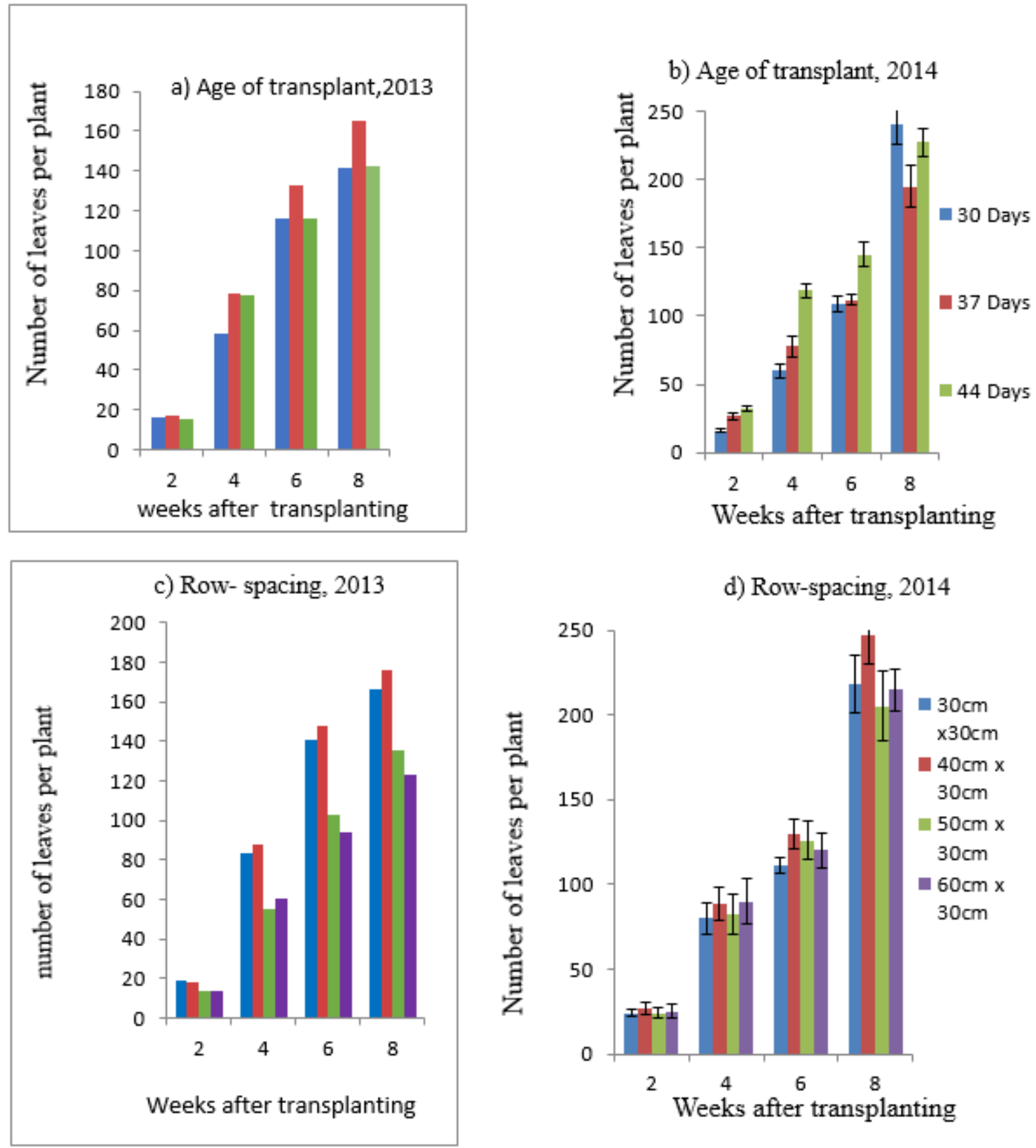

d) Row-spacing, 2014

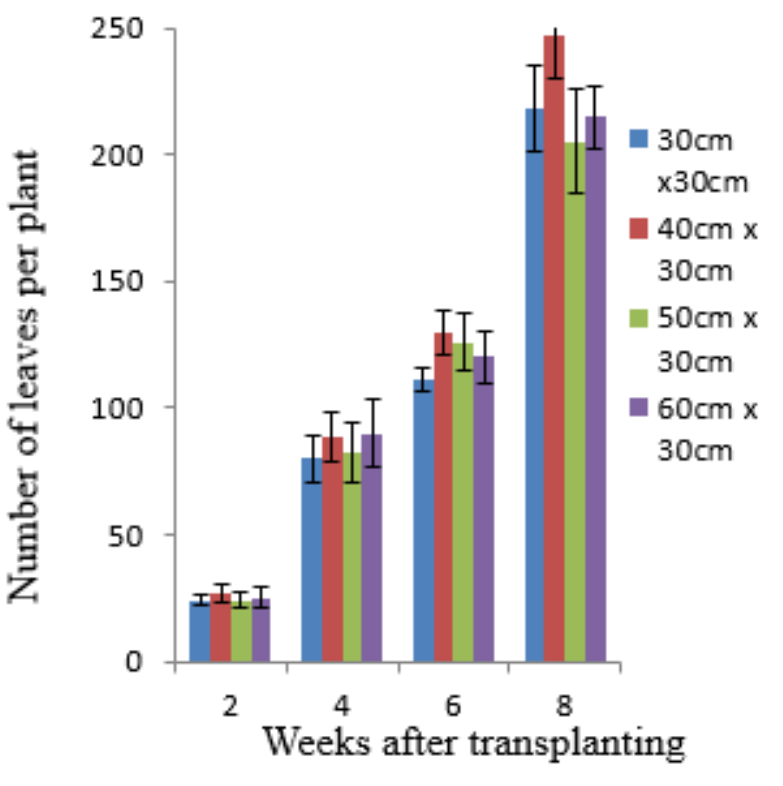

Fig.2: Effects of age of transplant and row-spacing on number leaves per plant of chilli pepper, 2013 and 2014 

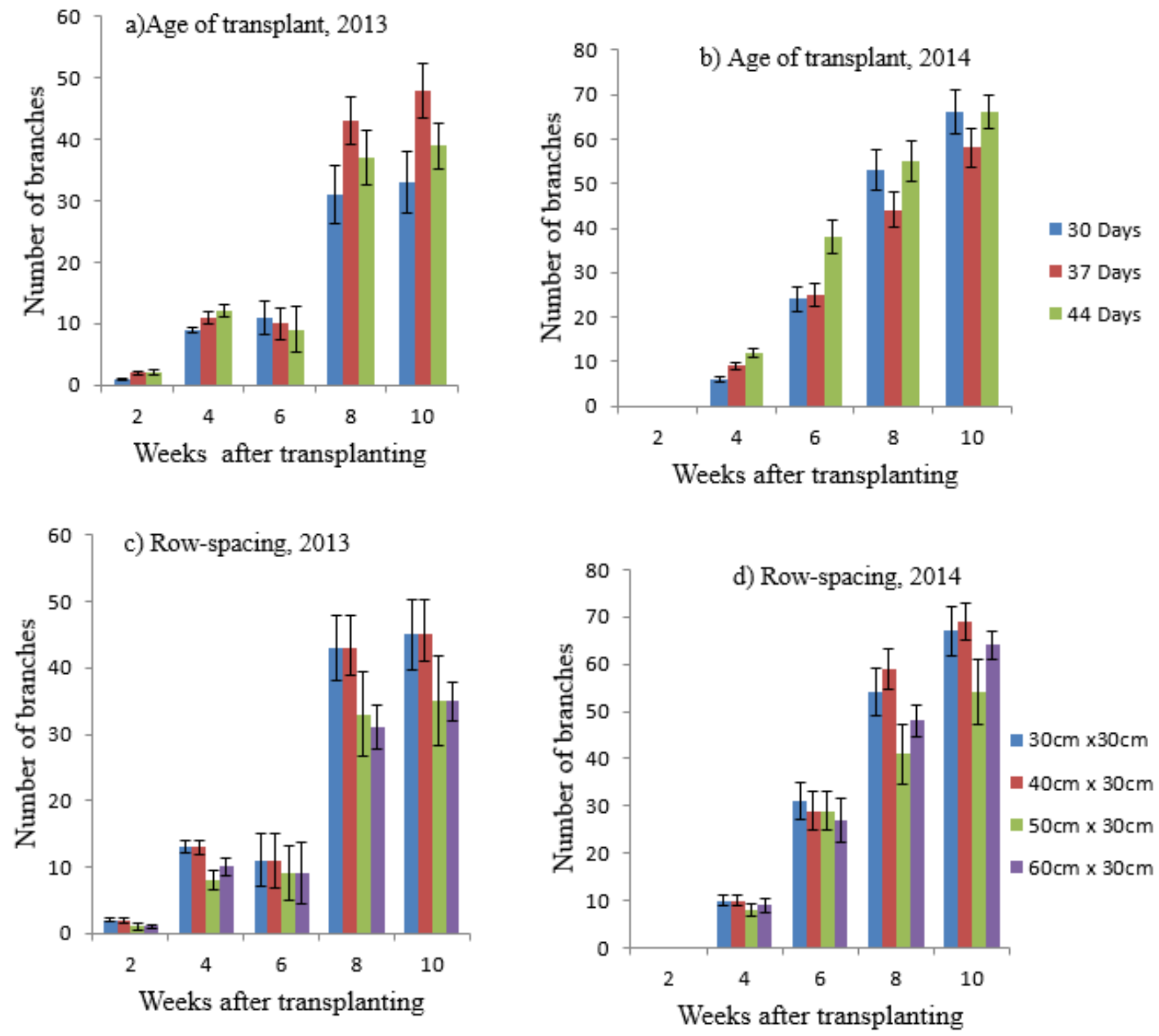

Fig.3: Effects of age of transplant and row-spacing on number of branches of chilli pepper, 2013 and 2014 


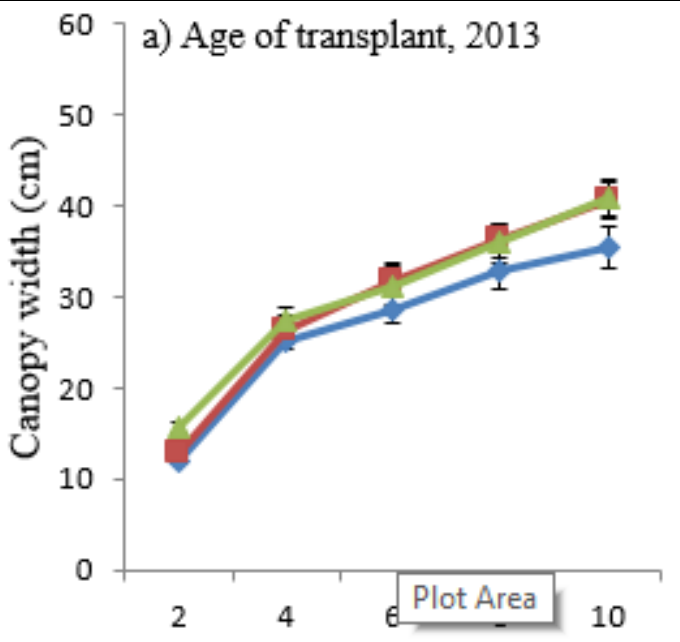

Weeks after transplanting

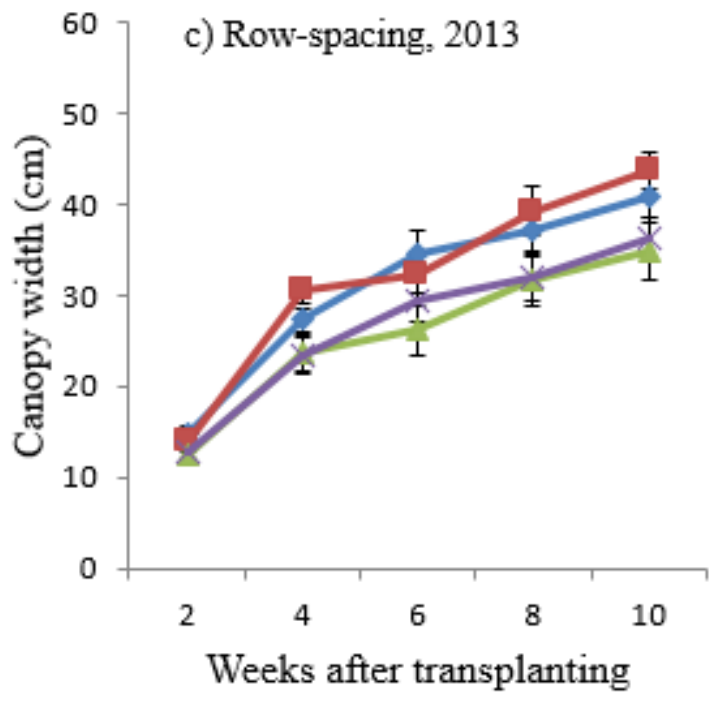

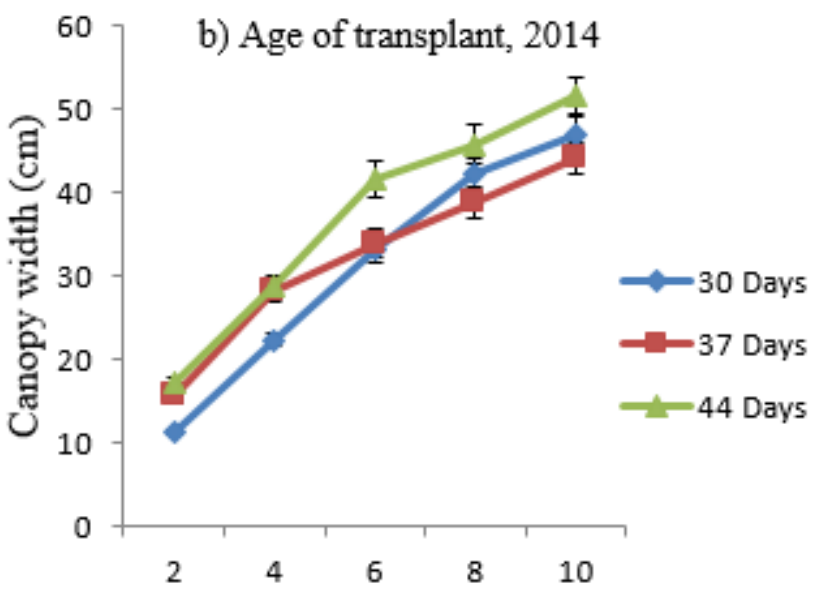

Weeks after tranplanting

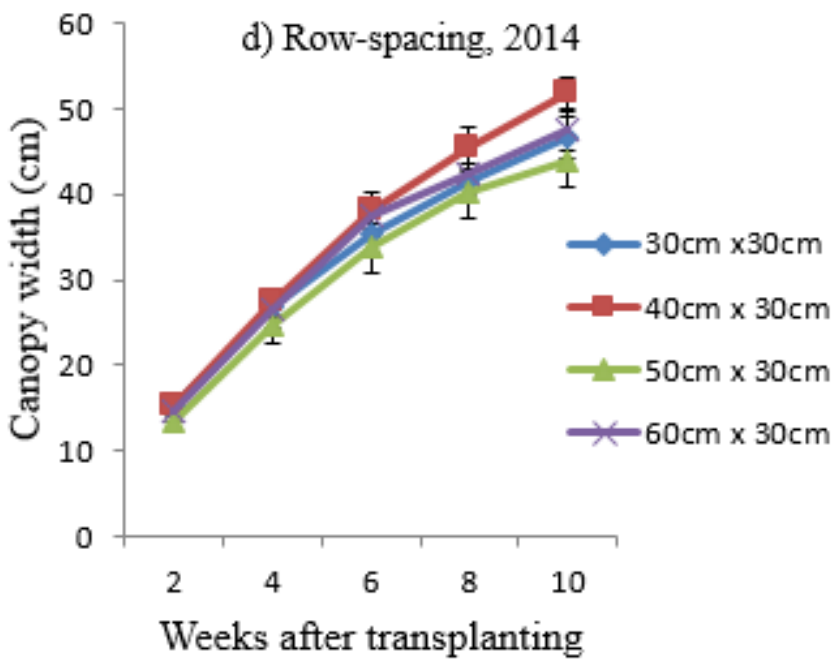

Fig.4: Effects of Age of transplant and row-spacing on canopy width of chilli pepper, 2013 and 2014 
a) Age of transplant, 2013
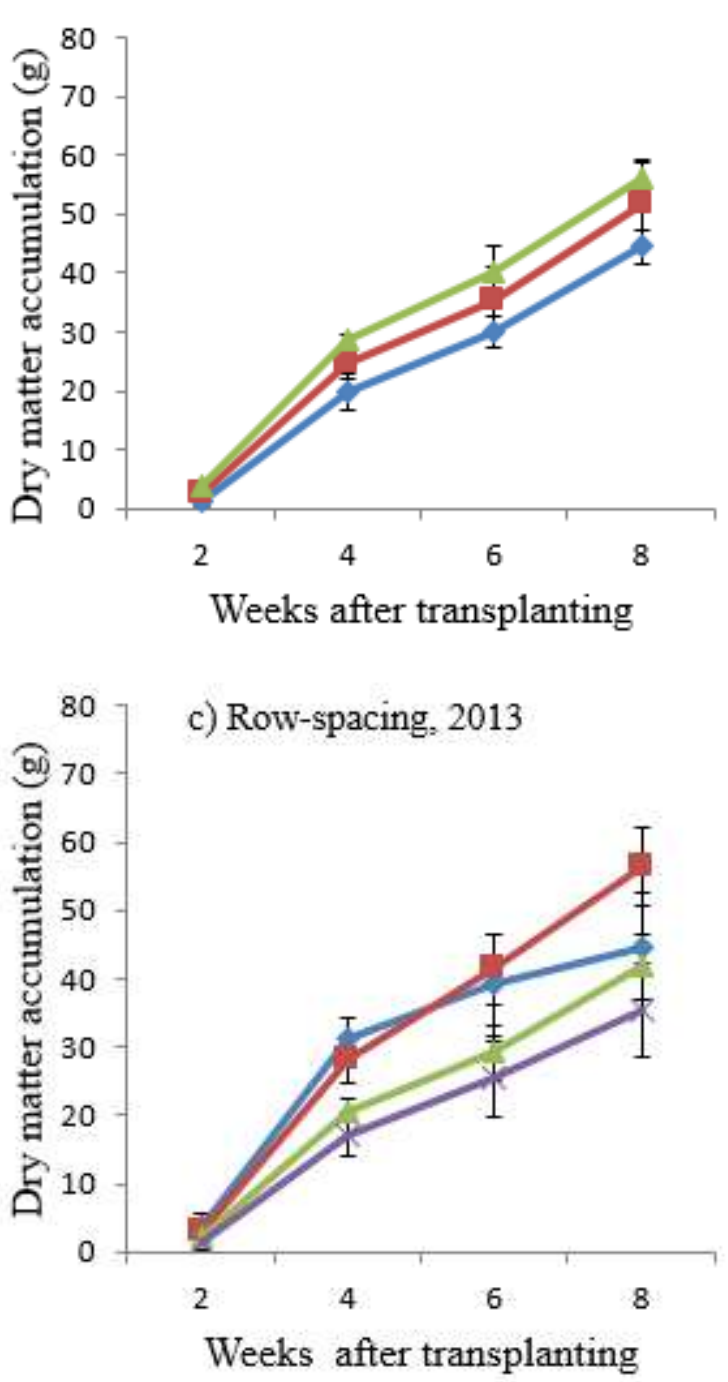

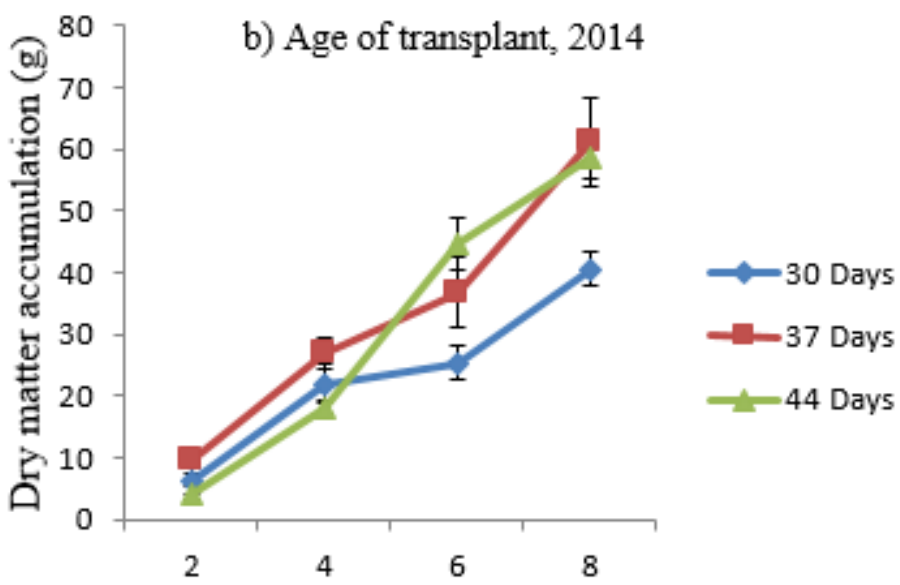

Weeks after transplanting

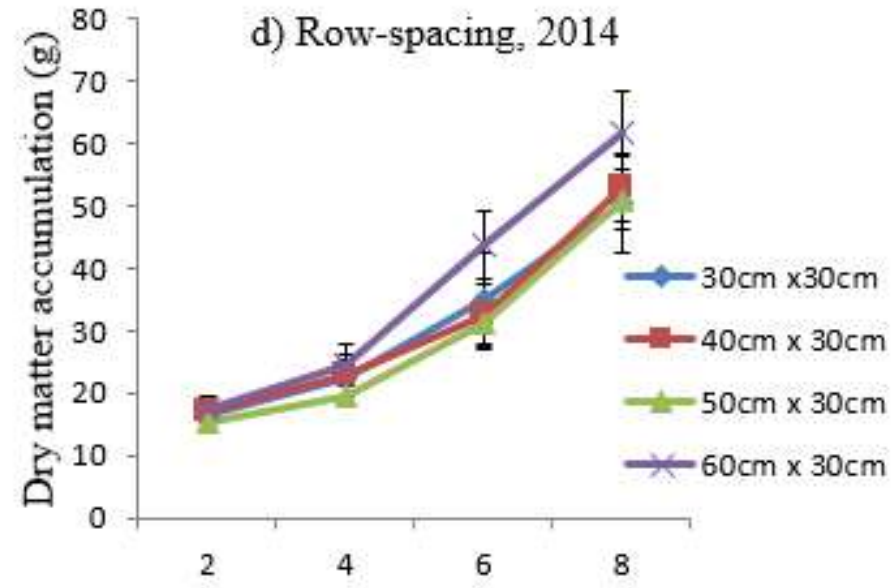

Weeks after transplanting

Fig.5: Effects of age of transplant and row-spacing on dry matter accumulation of chilli pepper, 2013 and 2014

\subsection{Yield and yield components}

\subsubsection{Number of Plants harvested}

There was no significant difference between ages of transplants in number of plants harvested during the 2013 cropping season. The 37 aged transplants differed significantly from the 30 aged transplants in number of plants harvested during the 2014 cropping season (Table 2). The 37 aged transplant had the highest number of plants harvested followed by the 44 aged transplants and the least by the 30 aged transplants during the 2014 cropping season (Table 2). High number of plants harvested in older aged transplants might be due to well established root system in older seedlings which was capable of causing enhanced water absorption and translocation along with nutrients from the rhizosphere. This agrees with the findings of
(Safina-Naz et al., 2006 ; Yr. Shukla and Rajender, 2011) that older transplants with sufficient roots and number of true leaves might be responsible for absorbing soil water and manufacturing a sizable amount of photosynthates required to establish vigorous plant and complete its life cycle more comfortably.

There was no significant difference between row spacing in number of plants harvested during the 2013 and 2014 cropping seasons (Table 2).

\subsubsection{Number of fruits per plant}

The 30 aged transplants differed significantly from the 37 aged transplants in number of fruits per plant during the 2013 cropping season (Table 2). This might be due to young seedlings transplanted. This agrees with the findings of 
(Adelana, 1983) who reported of highest number of fruits from younger transplants. Contrary to this (Renuka and Perera, 2002) found more fruits from older transplants. There was no significant difference between 37 and 44 aged transplants in number of fruits per plant at the same cropping period (Table 2). There was no significant difference between ages of transplants in number of fruits per plants during the 2014 cropping season although there were differences between treatment means. The 37 aged transplants produced the highest number of fruits per plant followed by the 44 aged transplants and the least with 30 aged transplants (Table 2). This might be due to the fact that in younger seedlings there was less storage of food needed for vegetative extension, whereas, older transplants were mature enough and limit vegetative extension. Moreover, middle aged seedlings on account of extended lateral branches produced maximum number of fruits per plant than younger or older ones. This is in conformity with the findings of (Yr. Shukla and Rajender, 2011) that middle aged transplants produced higher number of fruits per plant than the younger or older transplants. Highest number of fruits per plant by middle aged transplants was also reported by (Salik et al., 2000) in tomato.

Row spacing had no significant effect on number of fruits per plant in both cropping seasons although differences exist between treatment means. The $40 \times 30 \mathrm{~cm}$ row spacing had the highest number of fruits per plant in both cropping seasons (Table 2). The high number of fruits per plant in 40 x $30 \mathrm{~cm}$ row spacing might be due to better vegetative growth in terms of plant height, number of leaves per plant and number of branches in both cropping seasons.

\subsubsection{Fruit weight per plant}

There was no significant difference between ages of transplants in fruits weight per plant in both cropping seasons although the 30 and 44 aged transplants had the highest fruit weight per plant during the 2013 and 2014 cropping seasons respectively (Table 2). The $60 \times 30 \mathrm{~cm}$ row spacing differed significantly from $50 \times 30 \mathrm{~cm}$ in fruit weight per plant during the 2013 cropping season (Table 2). The high fruit weight per plant in $60 \times 30 \mathrm{~cm}$ row spacing might be due to differences in row spacing coupled with available soil mineral nutrients and high soil moisture content for the vegetative growth to the efficiency of photosynthesis which resulted into accumulation and translocation of photosynthates leading to efficient utilization of assimilates. There was no significant difference between row spacing in fruit weight per plant during the 2013 and 2014 cropping seasons (Table 2).

Table.2: Number of plants harvested, number of fruits per plant and fruit weight per plant as influenced by ages of transplant and row spacing during the 2013 and 2014 cropping seasons.

\begin{tabular}{|c|c|c|c|c|c|c|}
\hline \multirow[t]{2}{*}{ Treatment } & \multicolumn{2}{|c|}{$\begin{array}{c}\text { Number of plants } \\
\text { harvested }\end{array}$} & \multicolumn{2}{|c|}{$\begin{array}{c}\text { Number of fruits per } \\
\text { plant }\end{array}$} & \multicolumn{2}{|c|}{$\begin{array}{c}\text { Fruit weight per plant } \\
(\mathrm{g})\end{array}$} \\
\hline & 2013 & 2014 & 2013 & 2014 & 2013 & 2014 \\
\hline \multicolumn{7}{|c|}{ Age of transplant } \\
\hline 30 Days & 13.96 & 11.00 & 26.45 & 19.00 & 48.42 & 22.20 \\
\hline 37 Days & 13.03 & 20.00 & 22.87 & 26.00 & 38.07 & 24.90 \\
\hline 44 Days & 14.71 & 17.00 & 23.29 & 24.00 & 40.29 & 25.90 \\
\hline $\operatorname{LSD}(0.05)$ & NS & $6.00^{*}$ & $2.96^{*}$ & NS & NS & NS \\
\hline \multicolumn{7}{|l|}{ Row spacing } \\
\hline $30 \mathrm{~cm} \times 30 \mathrm{~cm}$ & 16.82 & 14.00 & 24.83 & 18.00 & 40.84 & 22.60 \\
\hline $40 \mathrm{~cm} \times 30 \mathrm{~cm}$ & 16.30 & 19.00 & 25.51 & 27.00 & 43.44 & 22.00 \\
\hline $50 \mathrm{~cm} \times 30 \mathrm{~cm}$ & 11.21 & 14.00 & 22.75 & 21.00 & 32.92 & 24.30 \\
\hline $60 \mathrm{~cm} \times 30 \mathrm{~cm}$ & 11.27 & 17.00 & 23.73 & 25.00 & 51.83 & 28.40 \\
\hline LSD (0.05) & NS & NS & NS & NS & $12.22 *$ & NS \\
\hline $\begin{array}{l}\text { Age } \mathrm{x} \text { row spa } \\
\text { interaction }\end{array}$ & NS & NS & NS & NS & NS & NS \\
\hline $\mathrm{CV}(\%)$ & 31.1 & 24.87 & 30.2 & 20.48 & 28.5 & 34.2 \\
\hline
\end{tabular}


3.2.4 Fruit Length

Ages of transplant showed no significant effect in fruit length during the 2013 cropping season (Table 3). There was a significant difference between 44 aged transplants from 30 aged transplants in fruit length during the 2014 cropping season (Table 3 ). The longest fruit length in the 44 aged transplants might be due to initial high rainfall and temperature during the cropping period that resulted in vigorous plant growth, especially development of deep roots for the uptake of soil moisture and nutrients for proper development of fruits. The shortest fruit length in 30 aged transplants might be due to low dry matter accumulated and less storage of food in terms of solutes needed for cellular elongation of fruits. There was no significant difference between row spacing treatments in fruit length in both cropping seasons although differences exist between treatments. The $60 \times 30 \mathrm{~cm}$ and $50 \times 30 \mathrm{~cm}$ had the longest fruit length during the 2013 and 2014 cropping seasons respectively (Table 3 ).

\subsubsection{Fruit diameter}

The 30 aged transplants differed significantly from 44 aged transplants in fruit diameter during the 2013 cropping season (Table 3). This might be due to differences in age of transplant of seedlings. This contradicts those found by (McCraw and Greig, 1986; Weston, 1988) that pepper transplants of 8 and 11 weeks (older transplants) have a yield advantage for early fruit size. The 44 aged transplants differed significantly from 30 aged transplants in fruit diameter during the 2014 cropping season (Table 3). The widest fruit diameter in 44 aged transplants might be attributed to high or enhanced biomass, accumulation of resources and improved water relationship in the plants. This heightened meristematic activities that favoured the enlargement of fruit. This agrees with the findings of (Vavrina, 1998) that due to slow growth habit of pepper, older transplants (i.e $>4$ to 6 weeks) may be advised. There was no significant difference between row spacing treatments in fruit diameter in both cropping seasons (Table 3).

\subsubsection{Fruit Yield}

There was no significant difference between ages of transplant in fruit yield during the 2013 cropping season although the older transplants had the highest fruit yield (Table 3). The 37 aged transplants differed significantly from the 30 and 44 aged transplants in fruit yield during the 2014 cropping season (Table 3). This might be due to enhanced initial plant growth due to high dry matter yield. Peppers require strong initial growth to promote earliness and abundant fruit set. The 30 aged transplants had the least fruit yield at the same cropping period (Table 3). This contradicts those found by (Ibrahim et al., 2013) that higher fresh fruit yield was recorded in pepper transplanted earlier than those transplanted later. The $30 \times 30 \mathrm{~cm}$ row spacing differed significantly from the $50 \times 30 \mathrm{~cm}$ and $60 \times 30 \mathrm{~cm}$ row spacing in fruit yield during the 2013 cropping season (Table 3). This might be due to differences in plant spacing and plant morphology. This agrees with the findings of (Rafiei, 2009; Albayrak et al., 2011; Ciampitti and Vyn, 2011) that for most crops, plant density has a major influence on crop yield and economic profitability. Yildiz and Abak (2003) attested that plant yield can be variable in high density according to branch numbers per plant and that more plant density in comparison with lower plant density will lead to higher yield. Similar findings was reported by (Alabi et al., 2014) that total fruit yield per hectare increased with higher population densities. Some other studies showed that increasing yield will follow by increasing plant density Cavero et al., (2001); Nyambi et al., (2004). Peppers and other plants grown in denser population tend to be taller and may set fruit higher on the plant than those grown in less dense planting Stofella and Bryan, (1988). There was no significant difference between row spacing treatments in fruit yield during the 2014 cropping season although the $40 \times 30 \mathrm{~cm}$ row spacing had the highest yield (Table 3). This implies that a further reduction in the row spacing would probably not be beneficial and so the $40 \times 30 \mathrm{~cm}$ spacing appears optimum and should be recommended for hot pepper production.

Table.3: Fruit length, fruit diameter and fruit yield as influenced by ages of transplant and row spacing during the 2013 and 2014 cropping seasons.

\begin{tabular}{lcccccc}
\hline Treatment & \multicolumn{2}{c}{ Fruit length $(\mathbf{c m})$} & \multicolumn{2}{c}{ Fruit diameter $(\mathbf{c m})$} & \multicolumn{2}{c}{ Fruit yield $(\mathbf{k g} / \mathbf{h a})$} \\
\hline 2013 & 2014 & 2013 & 2014 & 2013 & 2014 \\
\hline
\end{tabular}

Age of transplant

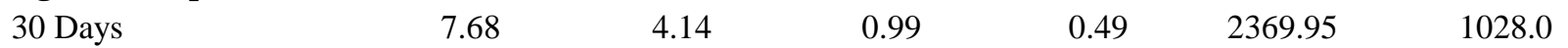




\begin{tabular}{|c|c|c|c|c|c|c|}
\hline 37 Days & 7.12 & 6.06 & 0.90 & 0.69 & 2089.97 & 2116.0 \\
\hline 44 Days & 7.60 & 6.13 & 0.89 & 0.78 & 2667.59 & 1542.0 \\
\hline $\operatorname{LSD}(0.05)$ & NS & $1.09^{*}$ & $0.09^{*}$ & $0.15 *$ & NS & $369.3 *$ \\
\hline \multicolumn{7}{|l|}{ Row spacing } \\
\hline $30 \mathrm{~cm} \times 30 \mathrm{~cm}$ & 7.12 & 5.13 & 0.96 & 0.64 & 3749.23 & 1415.0 \\
\hline $40 \mathrm{~cm} \times 30 \mathrm{~cm}$ & 7.22 & 5.60 & 0.94 & 0.66 & 2925.20 & 1843.0 \\
\hline $50 \mathrm{~cm} \times 30 \mathrm{~cm}$ & 7.57 & 6.03 & 0.90 & 0.73 & 1295.62 & 1531.0 \\
\hline $60 \mathrm{~cm} \times 30 \mathrm{~cm}$ & 7.96 & 5.02 & 0.92 & 0.60 & 1533.30 & 1459.0 \\
\hline LSD (0.05) & NS & NS & NS & NS & $984.40 *$ & NS \\
\hline $\begin{array}{l}\text { Age } x \text { row spa } \\
\text { interaction }\end{array}$ & NS & NS & NS & NS & NS & NS \\
\hline CV (\%) & 24.5 & 23.9 & 25.6 & 26.9 & 40.7 & 27.9 \\
\hline
\end{tabular}

\section{CONCLUSION}

Farmers are encouraged to transplant chilli pepper seedlings at 44 days after planting and at a row spacing of $40 \times 30 \mathrm{~cm}$ for taller plant, higher vegetative biomass and higher number of fruits per plant. For longer fruit, wider fruit diameter and higher fruit weight per plant, pepper farmers should transplant chilli pepper seedlings at 30 days after planting and at a row spacing of $60 \times 30 \mathrm{~cm}$. However, for taller plant, wider fruit diameter and higher fruit yield farmers are to transplant chilli pepper seedlings at 44 days after planting and at a row spacing of $30 \times 30 \mathrm{~cm}$.

\section{ACKNOWLEDGEMENT}

The Authors wish to acknowledge the Management of the University of Education, Winneba, College of Agriculture Education, Mampong-Ashanti Campus for the provision of land for this work, to Crop Research Institute of CSIR in Kumasi for the provision of planting material. Finally, thanks to the students of University of Education, Winneba, College of Agriculture Education, Mampong-Ashanti Campus for helping in the field work.

\section{REFERENCES}

[1] Adelana, B. O. (1983). Effects of age of transplants on the growth and yield of tomato (Lycopersicon esculentum Mill). Acta Horticulturae 123: 207- 216.

[2] Alabi, E. O., Ayodele, O. J. and Aluko, M. (2014). Growth and yield responses of bell pepper (Capsicum апnиит, rodo'variety) to in-row plant spacing. Journal of Agricultural and Biological Science. 9( 11): 389397
[3] Albayrak, S., Türk, M and Yüksel, O. (2011). Effect of row spacing and seeding rate on hungarian vetch yield and quality. Turkish J. Field Crops.16 (1): 54-58.

[4] Cavero, J., Ortega Gil, R., and Gutierrez, M. (2001). Plant density affects yield, yield components and colour of direct-seeded paprika pepper. HortScience 36(1), 76-79.

[5] Ciampitti, I.A. and Vyn. T.J. (2011). A comprehensive study of plant density consequences on nitrogen uptake dynamics of maize plants from vegetative to reproductive stages. Field Crop Res. $121: 2-18$.

[6] FAOSTAT (2011). Statistical Database of the Food and Agriculture of the United Nation.

[7] Ibrahim1, H. M. Olasantan, F. O. and Oyewale, R. O. (2013). Age of seedling at transplanting influenced growth and fruit yield of sweet pepper (Capsicum annuит L. cv. Rodo). Net Journal of Agricultural Science 1(4) : pp. 107-110

[8] Islam M., Saha S., Akand M.H. and Rahim M.A. (2011). Effect of spacing on the growth and yield of sweet pepper (Capsicum anпиum L). J. Central Euro. Agric. 12: 328- 335.

[9] Jiwon, L., KwangYong, K. and YoungMi, Y. (2001). Effects of nutrient solution strength, seedlings age, and container size on seedling quality and yield of spirit coloured bell pepper (Capsicum annum L). Journal of the Korean Society for Horticultural Science 42(3): 300-304.

[10] McCraw, B.D. and Grieg, J.K. (1986).Effect of transplant age and pruning procedure on yield and fruit-set of bell pepper. HortScience 21(3): 430-431 
[11] Millenium Development Authority (MiDA) (2010). Investment opportunity in Ghana chilli pepper production.www.mida.gov.gh

[12] Naser. A., El-Hendawy, S. and Schmidhalter, U. (2013). Influence of varied plant density on growth, yield and economic return of drip irrigated faba bean (Vicia faba 1.). Turkish Journal of Field Crops 18(2): 185-197

[13] Nyambi, G., Koona, P., Egunjobi, J. and Awodoyin, R. (2004). Growth and frequency and plant spacing. Trop. Science 44: 92-94.

[14] Rafiei, M. (2009). Influence of tillage and plant density on mung bean. Am.-Eurasian J. Sustain. Agric., 3(4): 877-880.

[15] Renuka, K. A. and Perera, K. D. A. (2002). Effect of seedling age its management on growth and yield of chilli. Annals of Sri Lanka, Department of Agriculture 4: 33-38.

[16] Safina-Naz, Muhammad, A. A. and Ishtiaq, A. (2006). Growth of chilli (Capsicum annuum L) F1 hybrid 'Sky Line- 2' in response to different age of transplants. Journal of Research (Science), Bahauddin Zakariya University, Multan, Pakistan 17(2): 91-95.

[17] Salik M. R, Muhammad, F. and Pervez, M. A. (2000). Relationship between age of seedlings on productivity of tomato (Lycopersicon esculentum L.) grown under plastic tunnel. Pakistan Journal of Biological Sciences 3(8): 1260-1261.

[18] Sarfo-Kantanka, O. and Lawson, N.C. (1980). The effect of different row spacing and plant arrangements on soyabeans. Canadian J. Plant. Sci. 60: 227-231

[19] Sayed, A. V. and Hossein, A. F. (2010). Effects of planting density and pattern on physiological growth indices in maize (Zea mays L.) under nitrogenous fertilizer application. Journal of Agricultural Extension and Rural Development 2(3): pp. 040-047.

[20] Statistical Analysis System, SAS, (2002). SAS user's guide statistics 2002 ed. Statistical Analysis System Institute, version 9.0, Cary, NC.

[21] Stofella, P.J. and Bryan, H.H. (1988). Plant population influences growth and yields of bell pepper. J. Amer. Soc. Hort. Sci. 113: 835-839

[22] Vavrina, C. S. and Armbrester, K. (1991). Effect of transplant age and cell size on pepper production. SWFREC Res. Rpt. IMM. 91-98

[23] Weston, L. (1988). Effect of flat cell size, transplant age, and production site on growth and yield pf pepper transplants. HortScience 23: 709-711
[24] Weston, L.A. (1988). Effect of flat cell size, transplant age and production site on growth and yield of pepper transplants. Hortscience 22(4) : 709-711

[25] Yildiz, D., H., and Abak, K. (2003). Effects of plant density and number of shoots on yield and fruit characteristics of peppers grown in Glasshouses. Turkey Journal of Agriculture 27: 29-35.

[26] YR SHUKLA, T. C. and RAJENDER, S. (2011). Effect of age of transplants on growth and yield of capsicum. International Journal of farm sciences 1(2): $56-62$ 